\title{
Specific heat of difficultly fusible metals
}

\section{H. Mache}

To cite this article: $\mathrm{H}$. Mache (1897) Specific heat of difficultly fusible metals, Philosophical Magazine Series 5, 44:268, 292-292, DOI: 10.1080/14786449708621067

To link to this article: http://dx.doi.org/10.1080/14786449708621067

\section{Published online: 08 May 2009.}

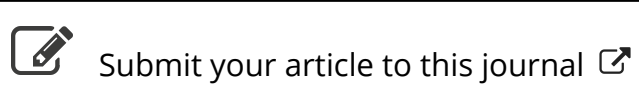

\footnotetext{
Џll Article views: 2
}

Q View related articles ¿ 
closing the current. The following are the principal results which he obtains :-

1. The internal resistance of the elements used (cylindrical glass vessels $2 \mathrm{~cm}$. in diameter, distance between the electrodes $3-4 \mathrm{~cm}$.) varied at ordinary temperatures between 40 and $80 \mathrm{ohms}$ according to the distance and magnitude of the electrodes.

2. The resistance varied considerably with the temperature, being trebled when it fell from $30^{\circ}$ to $5^{\circ}$.

3. No diminution of the interval resistance with the strength and duration of the current could be ascertained.

4. With stronger currents of 0.005 ampere (external resistance 200 ohms) polarization could be perceived even after 0.01 of a second. It increased but little during the first ten minutes, but afterwards more and more rapidly.

5. On opening the circuit the polarization diminished in a few minutes to a small fraction. Repeated short-circuiting through only 50 ohms' external resistance for more than a minute did not permanently injure the element.

6. When an element was closed for 2 hours through $200 \mathrm{ohms}$, by which its electromagnetic force was reduced almost to one half, in 2 minutes it attained its original strength to within 0.1 p.c. But after this the polarization set in more rapidly and strongly.Wiener Berichte, July 1897.

\section{SPECIFIC HEAT OF DIFFICULTLY FUSIBLE METALS. BX H. MACHE.}

Since the introduction of Moissan's method of reducing difficultly fusible metals by means of the electrical furnace it is possible to obtain these in a compact solid form, while previously they could only be had in powder. By this it is possible to obtain the specific heats with greater accuracy. By the aid of Bunsen's ice-calorimeter, palladium, chromium, vanadium, and tungsten were determined and the specific heats obtained: $\mathrm{Pd}=0 \cdot 0549, \mathrm{Cr}=0 \cdot 1208$, $\mathrm{V}=0 \cdot 1153$, Wo $=0.0336$. Wiener Berichte, July 1897.

DETERMINATION OF THE COEFFICIENT OF MAGAETIZATION OF

LIQUIDS AND THETR DEPENDENCE ON TEMPERATURE. BY PROF. DR. GUSTAV JÄGER AND DR. STEFAN MEYER.

The method is that of measuring the ascent in narrow tubes in the magnetic field which was produced by the large electromagnet of the Physical Institute. By taking special precautions considerably greater accuracy could be obtained than heretofore; the position of the meniscus was kept constant by increasing the pressure of a large volume of air. Solutions of magnetic salts in water were principally investigated.-Wiener Berichte, July 1897. 